\title{
Healthness - nowe wyzwanie dla kardiologii prewencyjnej
}

\author{
Healthness - a new challenge for preventive cardiology
}

\author{
Piotr Dylewicz ${ }^{1,2}$, Monika Krzywicka-Michałowska² \\ ${ }^{1}$ Sekcja Rehabilitacji i Fizjologii Wysiłku Polskiego Towarzystwa Kardiologicznego \\ ${ }^{2}$ Katedra Rehabilitacji Kardiologicznej Akademii Wychowania Fizycznego w Poznaniu
}

Niedawno na łamach czołowego niemieckiego czasopisma poświęconego prewencji i promocji zdrowia [1] ukazał się artykuł zatytułowany „Von Wellness zu Healthness”, dotyczący pewnej nowej tendencji w świecie turystyki, łączenia jej z procesem fachowej i rzetelnej dbałości o zdrowie oraz samoedukacji w tym zakresie. Trend ten nazwano healthness, a jego realizację osadzono znacznie mocniej na gruncie medycyny i rehabilitacji aniżeli z reguły skomercjalizowane zabiegi z zakresu wellness.

Podobnie jak autorzy uważamy, że w dobie coraz bardziej rozpowszechnionych chorób cywilizacyjnych dotychczas stosowane programy pierwotnej i wtórnej profilaktyki zdrowotnej wymagają wnikliwej analizy i istotnej zmiany. Konieczne są szersze działania dotyczące budowy odpowiedniego systemu, będącego integralną częścią systemu ochrony zdrowia, odpowiedzialnego za działania profilaktyczne, zabezpieczające przed chorobą lub jej nawrotem. Należy zaznaczyć, że - w przeciwieństwie do naszego kraju - władze ustawodawcze i wykonawcze Republiki Federalnej Niemiec w pełni dostrzegły ten problem i doprowadziły do uchwalenia narodowego programu działań prewencyjnych dotyczących zdrowia, przeznaczając na to znaczne środki. Istotą tej ustawy jest zapewnienie jak największej liczbie obywateli dostępu do tej oferty [2, 3].

Autorzy komentowanego opracowania proponują stworzenie odpowiedniej infrastruktury w postaci swoistych centrów zdrowia, być może przy częściowym przekształceniu istniejących obiektów typu wellness [1]. Zwracają uwagę na fakt, że poziom i zakres skomercjalizowania hasła wellness sprawiają, że nie oddaje ono w pełni istoty problemu profilaktyki zdrowotnej. Nie mając podłoża naukowego i trwałego powiązania z systemem ochrony zdrowia, hasło to stało się jedynie sloganem swoistej mody na odprężenie i powierzchowny dobrostan. Wellness nie znajduje uzasadnienia w udokumentowanych, prozdrowotnych efektach, takich jak na przykład redukcja podstawowych czynników ryzyka wystąpienia chorób, w tym również schorzeń układu krążenia.

Zdaniem autorów wspomnianego opracowania, które w znacznej mierze podzielamy, ochrona zdrowia powinna się opierać przede wszystkim na edukacji zdrowotnej społeczeństwa, ale także na zaoferowaniu możliwości prowadzenia prozdrowotnego stylu życia, chociażby w czasie wolnym. Zdajemy sobie sprawę, że motywacja i oczekiwania osób, które wybierają dotychczasową ofertę wellness - w odróżnieniu do tych, które chcą wyjechać w celach typowo zdrowotnych - są zupełnie inne. Profil uczestnika programu healthness będzie raczej kategorią pacjenta obsługiwanego przez fachowo wyszkolony personel medyczny posiadający niezbędną wiedzę nie tylko z zakresu patofizjologii, ale także fizjoterapii, w tym w szczególności zasad odpowiedniego dawkowania, rodzaju i poziomu aktywności fizycznej. Istotą tego typu placówek powinny być indywidualizacja oferty medycznej, holistyczne podejście do zdrowia, potrzeb i możliwości człowieka [1].

Powstanie swoistych centrów zdrowotności w okolicach licznie odwiedzanych w celach turystycznych i wypoczynkowych to także ciekawy rynek, na którym samoświadomość i samoocena gości stanowi podstawę realizacji pewnej oferty. Jednak healthness, nastawione na kształtowanie zdrowia, musi się także stać pewnym konstruktem naukowym, oparty na faktach.

Nasze polskie doświadczenia i działania w dziedzinie profilaktyki zdrowotnej, w tym także kardiologicznej, dotychczas ograniczały się głównie do przeprowadzania badań populacyjnych i stawiania diagnozy. Do wyjątków należały

Adres do korespondencji: dr n. kf. Monika Krzywicka-Michałowska, Katedra Rehabilitacji Kardiologicznej, Akademia Wychowania Fizycznego, ul. Królowej Jadwigi 27/39,61-871 Poznań, e-mail: mkrzywicka@awf.poznan.pl 
próby podjęcia interwencji [3]. Wiąże się to z pewnością z dotychczasową polityką zdrowotną państwa, a zwłaszcza Narodowego Funduszu Zdrowia (NFZ), które głównie pod wpływem presji społecznej ze strony pacjentów ograniczają się prawie wyłącznie do finansowania medycyny naprawczej i nie mają odwagi w szerszym zakresie wesprzeć oferty prozdrowotnej. Nie można nie dostrzec, że takim stanem jest zainteresowana także szeroka grupa instytucji i osób związanych z ochroną zdrowia. W większości przypadków „żyjemy” przecież z chorych, a nie ze zdrowych, którzy nie chcą być chorzy. Czy jednak nie należy tego zmieniać?

Oczekujemy, że - być może - niniejszy esej będzie przyczynkiem do innego spojrzenia na cele medycyny, w tym także kardiologii w XXI wieku. Zdajemy sobie sprawę, że będzie to bardzo trudne. Nasza pierwsza próba sprzed kilku lat, gdy współautor tego artykułu wspólnie z Profesorami Ryszardem Piotrowiczem i Tomaszem Zdrojewskim złożyła wizytę ówczesnemu prezesowi NFZ dr. Andrzejowi Sośnierzowi, okazała się dla nas szokiem. Na naszą propozycję, aby NFZ na podobnej zasadzie, jak dofinansowuje pewne leki, zaczął częściowo dofinansowywać także kontrolowane medycznie programy aktywności fizycznej, skierowane do różnych grup zdrowych i chorych, usłyszeliśmy odpowiedź: „za gimnastyczkę nie będę płacił”.

\section{Piśmiennictwo}

1. Wieser A., Cassens M. Von Wellness zu Healthness. Über Bildungspotenziale im Gesundheitstourismus. Prävention und Gesundheitsförderung 2014; 9: 321. doi: 10.1007/s11553-014-0440-7.

2. Bundesministerium für Gesundheit Pressemitteilung. Mehr Gesundheitsförderung denn je - Bundestag beschließt das Gesetz zur Förderung der Prävention. Berlin 2013. Nr 49. Dostępne na: http://www. bmg.bund.de/presse/pressemitteilungen/2013-02/praeventionsfoerderungsgesetz-beschlossen.html. Data dostępu: 28.06.2013 r.

3. Zdrojewski T., Głuszek J., Posadzy-Małaczyńska A. i wsp. The effects of social intervention on detection and efficacy of treatment for arterial hypertension. Main results of the Polish Four Cities Programme. Kardiol. Pol. 2004: 61; 546-552. 